\title{
ECOLOGICAL AGRICULTURE - INCOME AND FOOD SOURCE FOR BIG CITIES. CASE STUDY MĂGURELE - BUCHAREST, ROMANIA
}

DOI: https://doi.org/10.18509/GBP210343p

UDC: $338.439 .4-057.1: 303.6(498.11)$

\author{
Bogdan Petre ${ }^{1}$ \\ Cristian Cazacu ${ }^{1}$ \\ Andrei Ducman ${ }^{1}$ \\ Nicoleta Bira ${ }^{2}$ \\ ${ }^{1}$ University of Bucharest, Faculty of Geography, Department of Human and Economic \\ Geography; Bucharest, Romania. \\ 2 'Nicolae Bălcescu' Highschool, Oltenita, Romania.
}

\begin{abstract}
Agriculture represents a vital area in the life of all communities, not only of urban ones but also of rural ones. The town of Măgurele is situated in the south-western part of Bucharest Municipality with which it borders directly. Being a former village, in this town people are still engaged in agriculture, and the agricultural produce harvested in Măgurele supply the food markets in the western and and southern parts of the capital. Our study has the objective of presenting the importance of this field of economic activity, trying to emphasize the importance of its role in the life of the small urban community in Măgurele. The research also aims at presenting the financial contribution of agriculture for the local farmers, trying to establish the increase in population income due to agricultural activities. The research methodology had as a first stage the analysis of the questionnaire applied to a sample of 217 people residing in the town of Măgurele who are engaged in organic agriculture, part of them using modern means while the other part uses traditional means. A second stage was represented by grouping the respondents in age groups and means used in agricultural production. Finally, agricultural productions over several years were analysed taking into account the age groups. Results show that agricultural production of farmers in the group age 35-55 who used modern agricultural means and techniques was higher on surface unit, thing was also visible in the higher income as compared to the agricultural production of farmers over 55 years old who use traditional means and techniques which was lower on surface unit and therefore the income obtained was lower. Overall, the population income obtained from agriculture rose, even if not significantly, but in the current circumstances any additional income is auspicious. Analysing the evolution of agricultural production in the past years it can be ascertained that the transition to organic agriculture is on an ascending trend. The research is currently in the beginning stage, but in the future we aim to track the progress of the phenomenon and its socio-economic impact on the study area.
\end{abstract}

Keywords: economy, urban, geography, Bucharest, ecology

\section{INTRODUCTION}

The agricultural sector is one of the most important sources of income for small rural and urban communities, contributing to the diversified and highly branched economic development of communities, allowing the population to be engaged in lucrative processes that could generate main or secondary income [1][8][11]. Also, agriculture can 
be a secondary activity for people who own a business, for people in retirement, people with an agricultural profile (who have completed agricultural universities), allowing a general character and accessibility for all socio-economic categories. human and socioprofessional [2][5][9]. Due to the importance of agriculture at the economic level of any society, this is an activity that will not show decreases in intensity, being necessary to obtain internally (nationally) agricultural products [3][10]. For the locality of Magurele we are talking about a secondary activity, being in a process of transition to the tertiary and quaternary sectors, wanting to penetrate the enterprises on the field of services, offering permanent incomes, not seasonal ones like agriculture [4][6][7]. Also, an important element for the development of the agricultural fund of Magurele is the presence of an extremely vast territorial space, the possibility of expansion in the southern part of the city offers positive development prospects of this sector, in terms of increased export accessibility (through the presence of Bucharest Ring Motorway), but also through increased labor force capacity.

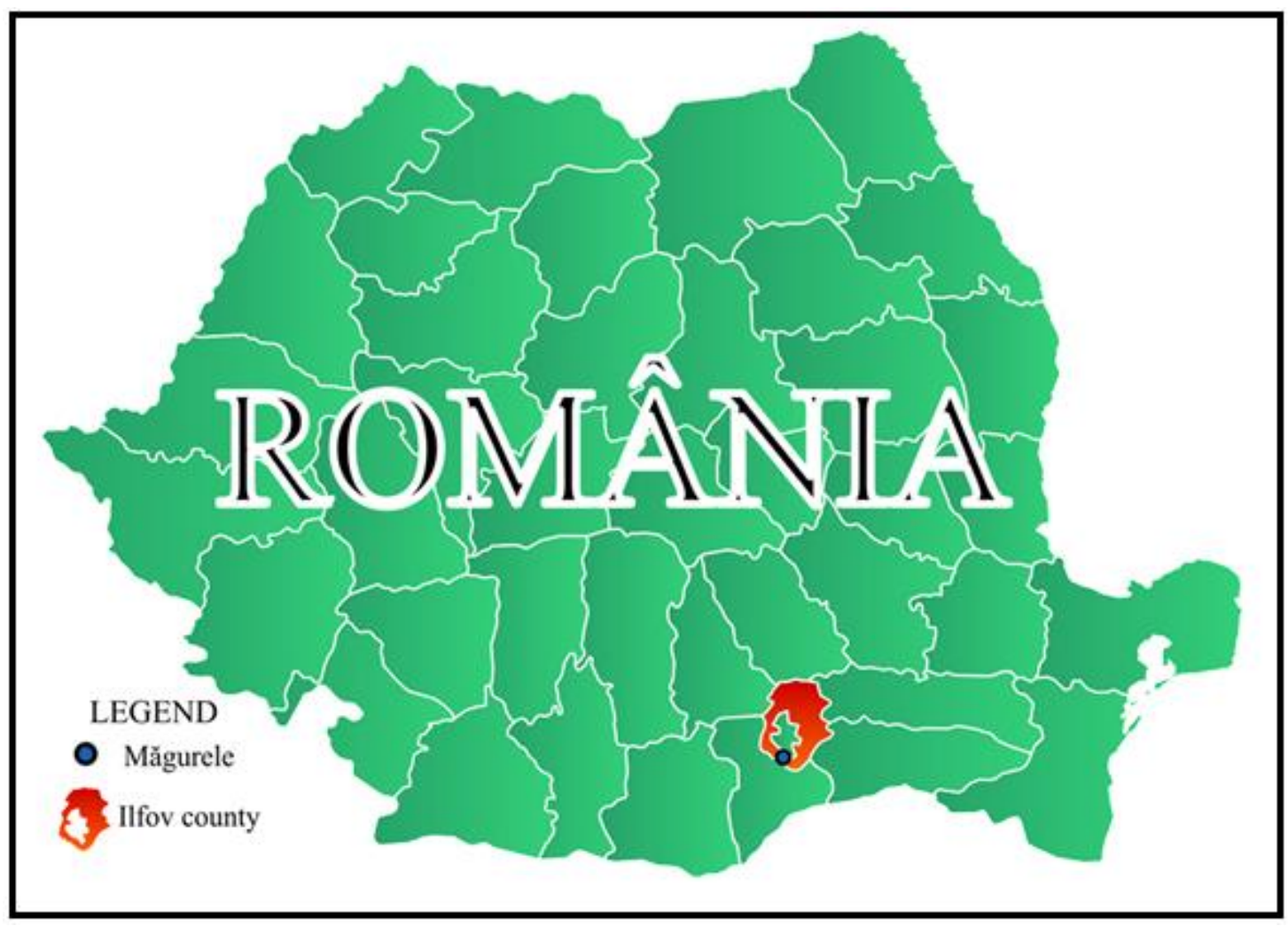

Figure 1. Magurele city location map (nationally and locally

The research was carried out through a physical questionnaire campaign, which was carried out during the period of maximum agricultural intensity of 2020, carried out over a period of seven days, directly in the city of Ilfov. Through the direct discussion with the human component, statistical data can be obtained, regarding the elements of human and economic interest, and through conversations with them, qualitative opinions can be obtained regarding the development of the agricultural sector on the territory of the Ilfov city. The challenges launched by the SARS-CoV-2 virus pandemic did not prevent agriculture from developing, still being an important element, so that the questionnaire campaign was much easier to carry out, by directly questioning the population in the process of obtaining agricultural products. . The questionnaire campaign obtained a total 
of 217 unique questionnaires, which were selected and centralized to obtain statistical data, using the Microsoft Office bundle, especially Microsoft Excel. By creating an application questionnaire, the study obtains the necessary authenticity and intervenes directly in the mentality, attitude and behaviors of the people involved in the agricultural sector.

\section{RESULTS}

The questionnaire campaign revealed that $60 \%$ of the respondents have agriculture as their main sector of activity, obtaining majority revenues from the sale of agricultural products obtained, mainly on domestic markets and markets in Bucharest. This category of respondents obtains the highest incomes among the surveyed respondents, investing time and financial resources to technologize the agricultural process, expand the agricultural fund, but also to employ the population in personal lands, in order to obtain increased monthly income. $33 \%$ of the respondents have agriculture as a secondary activity, not being directly involved in physical work, but only landowners or entrepreneurs, or qualified personnel (based on the completion of a university with an agricultural profile). Only $4 \%$ of the respondents have agriculture as a hobby, mainly the owners of small agricultural lands or large yards, and 3\% of the respondents are not introduced at all in the agricultural process. (Figure 2).

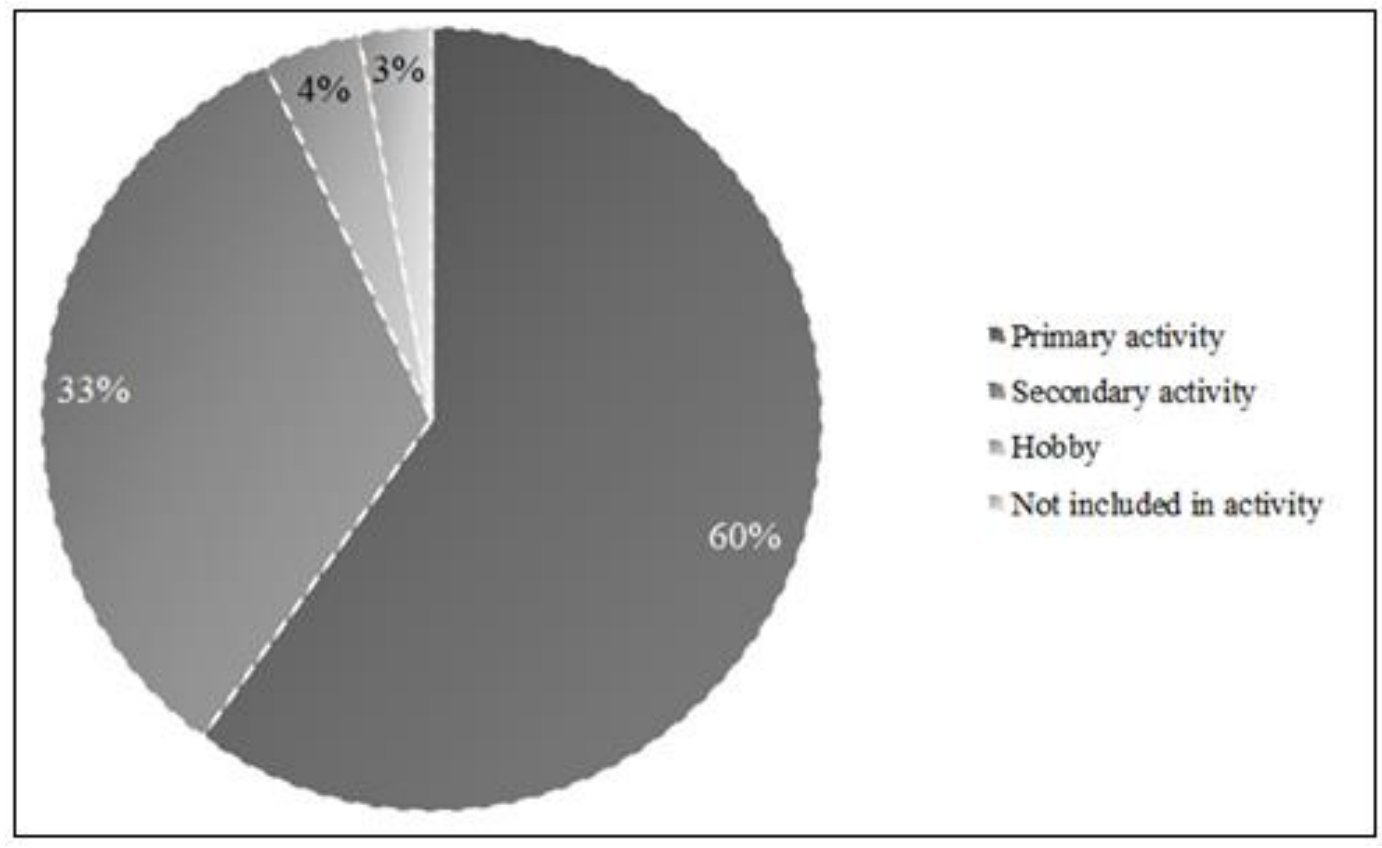

Figure 2. The importance of the agricultural sector in increasing individual incomes (according to the sample of the questionnaire campaign) 


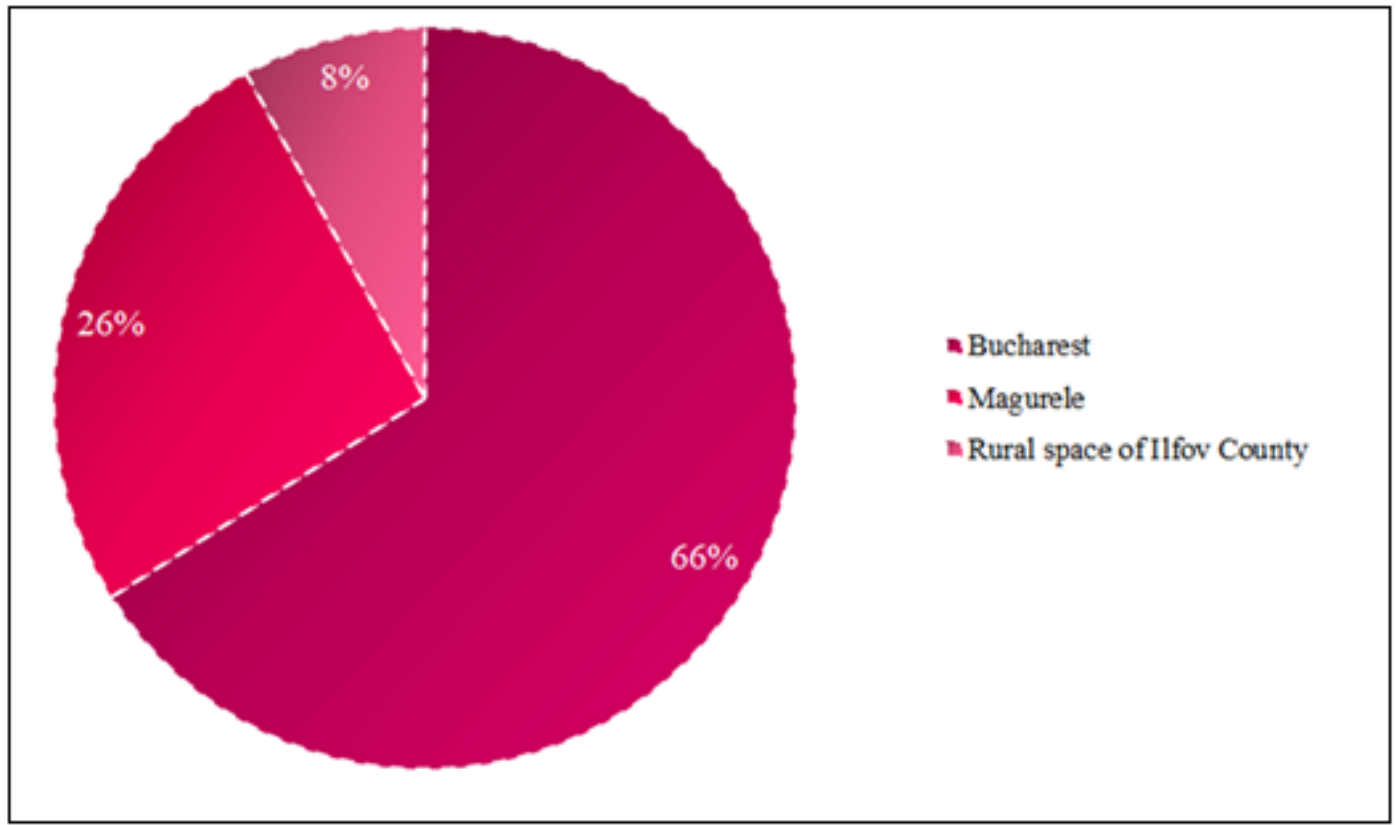

Figure 3. Marketing areas of agricultural export products (according to the sample of the questionnaire campaign)

$66 \%$ of the farmers surveyed in the questionnaire campaign sell their products on more important markets in Bucharest, through an increased potential to sell products, but also through easy accessibility to this economic space, no huge travel costs required . Mainly, the farmers who move to Bucharest are between 18 and 55 years old, wanting to obtain active incomes from the agricultural sector. $26 \%$ of respondents sell products locally, this category being the correspondent of farmers over 55 years, while only $8 \%$ of respondents sell products in rural markets of Ilfov County, considering that the agricultural potential in the area is much higher, selling only due to private partnerships. (Figure 3)

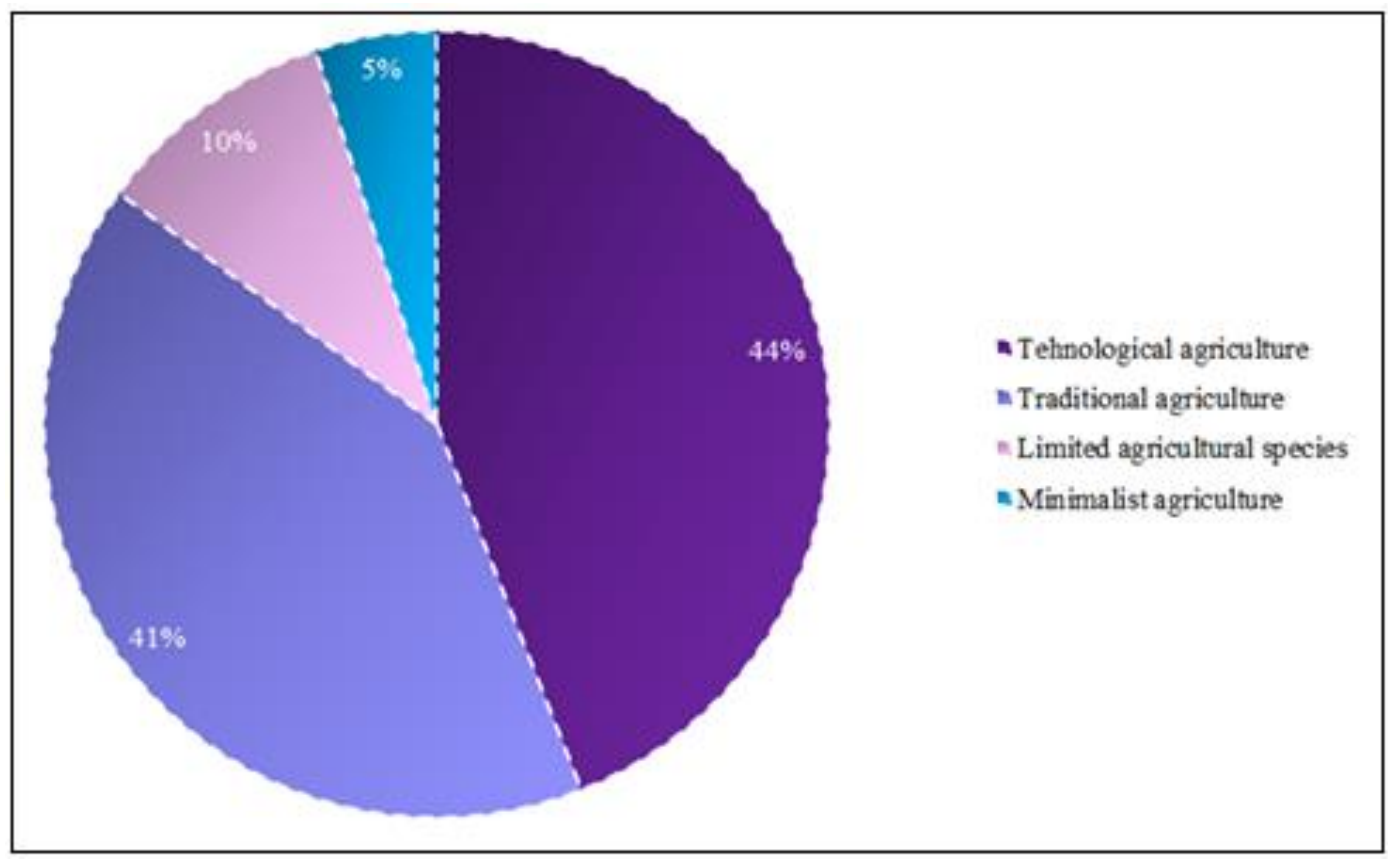

Figure 4. The main ways of developing the agricultural sector (according to the sample of the questionnaire campaign) 
Global technological development also proposes changes in the agricultural sector, and $44 \%$ of respondents consider elementary technology in obtaining agricultural products, as it facilitates physical labor, reduces daily working hours and reduces the need for investment in labor, but $41 \%$ of farmers believe that the technology is not necessary in the agricultural sector, they want to do the work on their own, only with the help of traditional equipment (such as tractor, irrigation systems). $10 \%$ of respondents opt for a limited agriculture in terms of number of crops, wanting only to obtain secondary incomes, without high costs of purchasing seeds or labor, channeling energy to completely necessary crops, and $5 \%$ of them have a minimum agriculture, carried out in personal yards, obtaining only one or a maximum of two agricultural crops in extremely small quantities, for personal use. (Figure 4)

Also, $56 \%$ of the respondents involve their family in the process of obtaining agricultural products, agriculture representing a family inheritance, especially for young males who do not want to migrate to Bucharest. $34 \%$ of the respondents carry out agriculture in personal form, either individually on less extensive lands, or in the form of agricultural enterprises, with a number of employees, not being directly involved in agricultural physical work. $10 \%$ of the respondents are employed in agricultural companies in Magurele. (Figure 5).

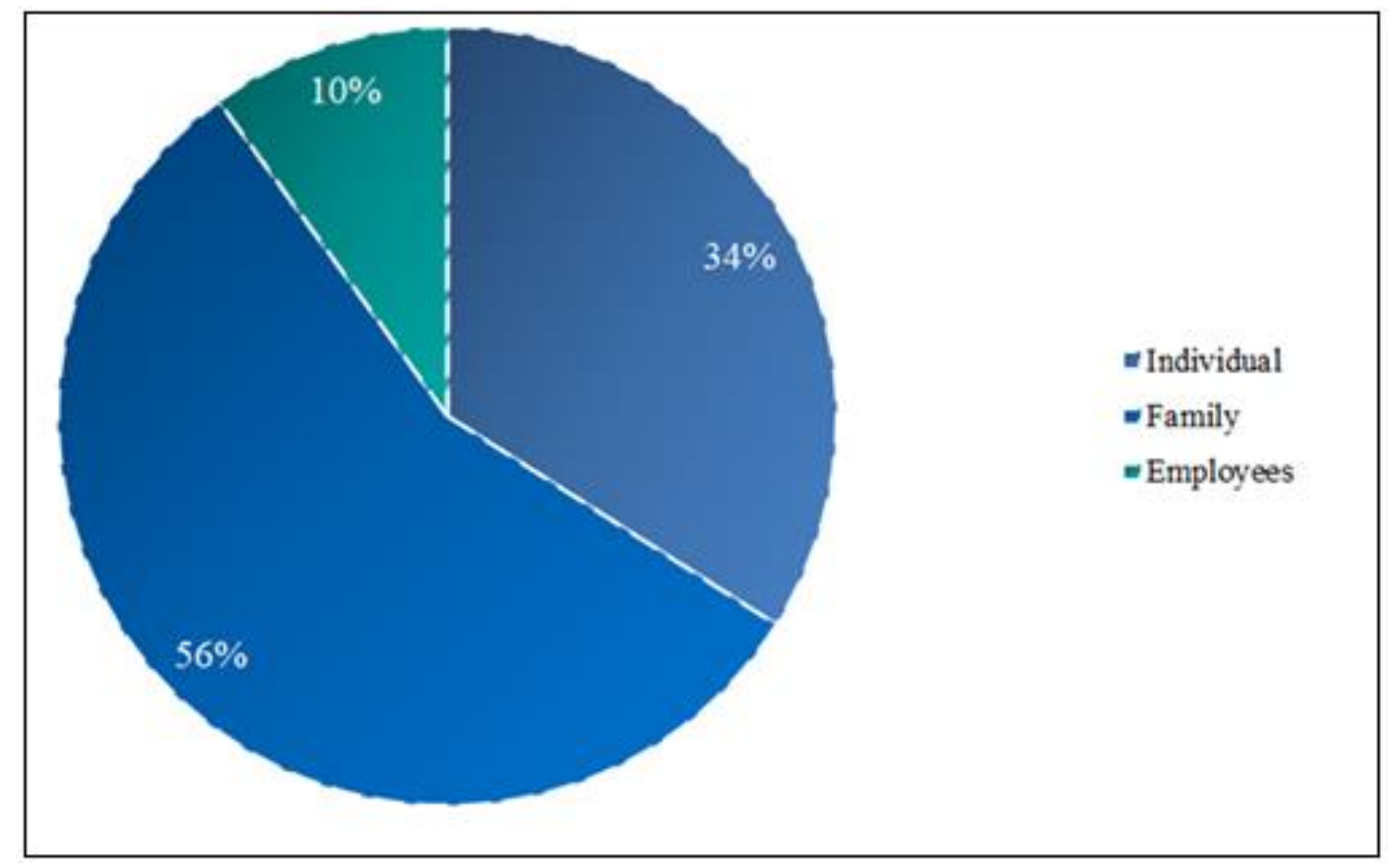

Figure 5. The main ways of carrying out the agricultural process (according to the sample of the questionnaire campaign)

The questionnaire campaign reveals that a large part of farmers choose to use agricultural products in their own households, accounting for over $50 \%$ of all respondents, while $78 \%$ of respondents aim to achieve agriculture to export products to local markets or markets from Bucharest. 32 of the respondents opt for the commercialization of the products from their own households, in an unorganized form, carrying out the sales only to the persons within the community who need certain agricultural products. It is important to mention that seven of the respondents did not want to provide details on the use of agricultural products obtained by them. (Figure 6). 


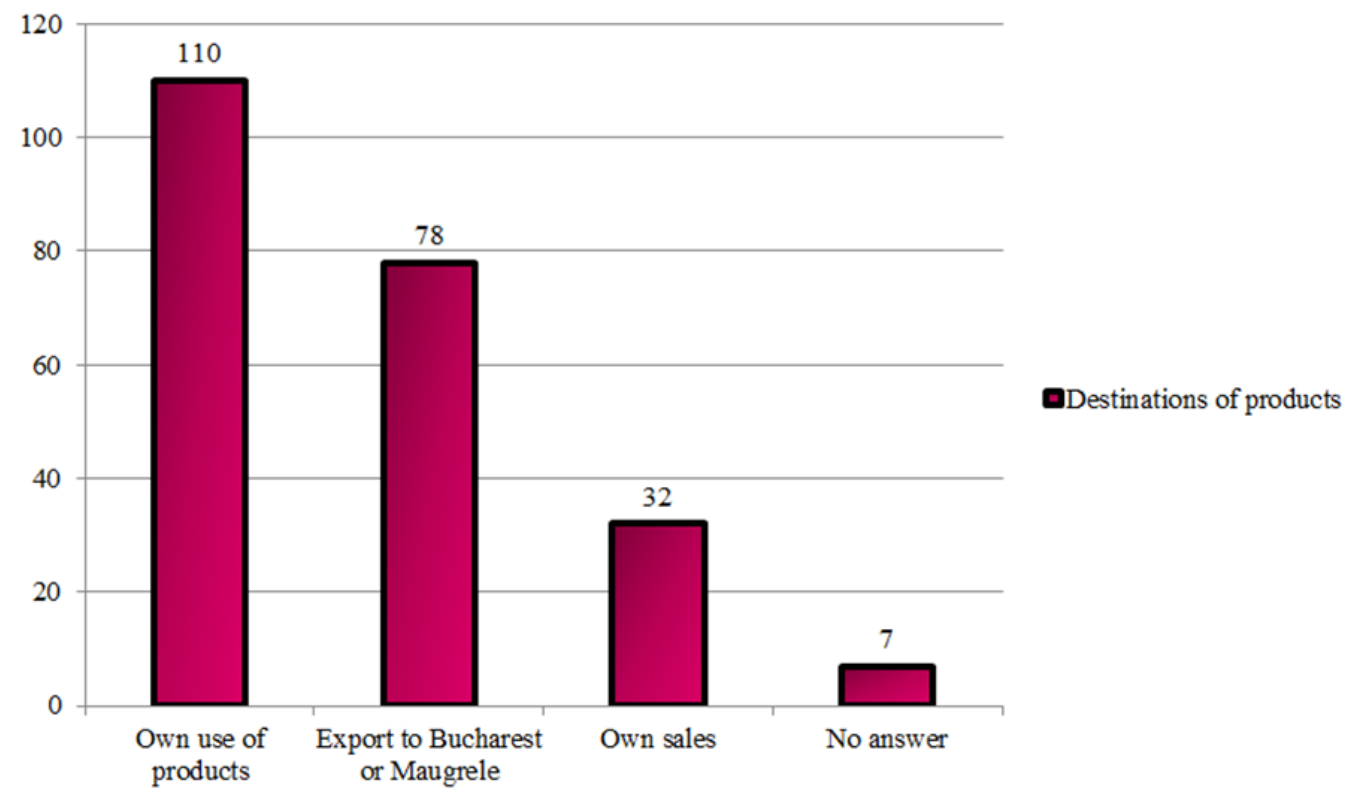

Figure 6. Use of products obtained from the agricultural sector (according to the sample of the questionnaire campaign)

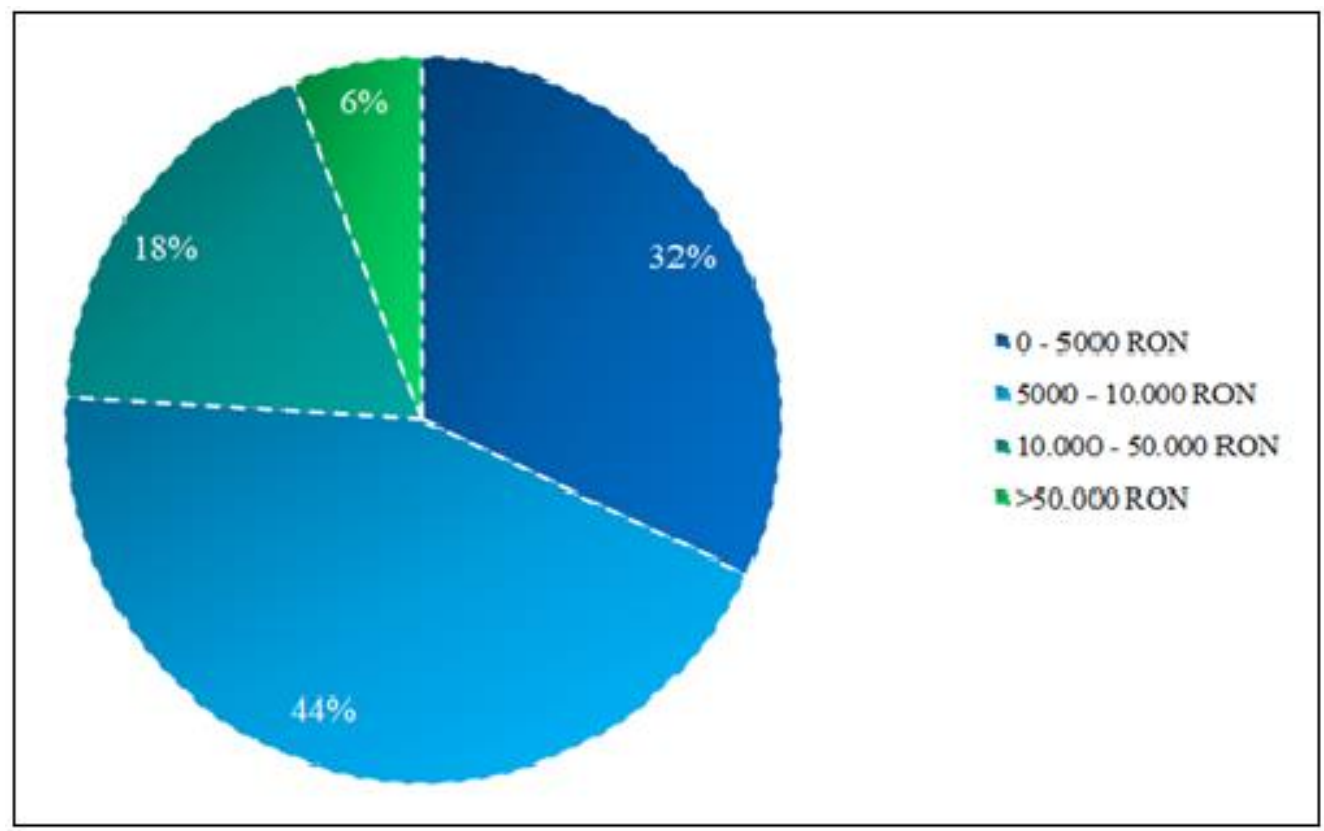

Figure 7. Average monthly income obtained from the agricultural sector (according to the sample of the questionnaire campaign)

The average monthly incomes in the agricultural sector are dependent on the time, space and intensity from which the respective activity benefits, as well as on a beneficial administration. $77 \%$ of the respondents obtain average monthly incomes below RON 10,000 , discussing respondents who have agriculture as a secondary activity or hobby, but also the elderly who produce agricultural products, but do not sell on more financially useful markets, preferring the local plan. $18 \%$ of the respondents get over 10,000 RON per month, with a maximum of 50,000 RON, this category being the correspondent of farmers who have exclusively agricultural activities, large spaces, have made massive investments and have a high degree of technology. $6 \%$ of the respondents obtain over RON 50,000 from the agricultural sector, this category being the correspondence of the 
respondents who run important agricultural enterprises, with a high number of employees and exclusively agricultural capital. (Figure 7)

It is important to mention that $41 \%$ of the respondents have an experience of 6-10 years in the agricultural field, being the dominant category of the indicator (corresponds to the respondents of 18-35 years), followed by the category of respondents with a minimum experience of 10 years, with a presence of $39 \%$ (corresponds to respondents aged 35 to 55). $14 \%$ of respondents have a maximum experience of 5 years in the agricultural sector (corresponds to the youngest respondents), while only $6 \%$ of respondents have an experience of over 20 years in the agricultural sector, especially among respondents over 55 for years. (Figure 8).

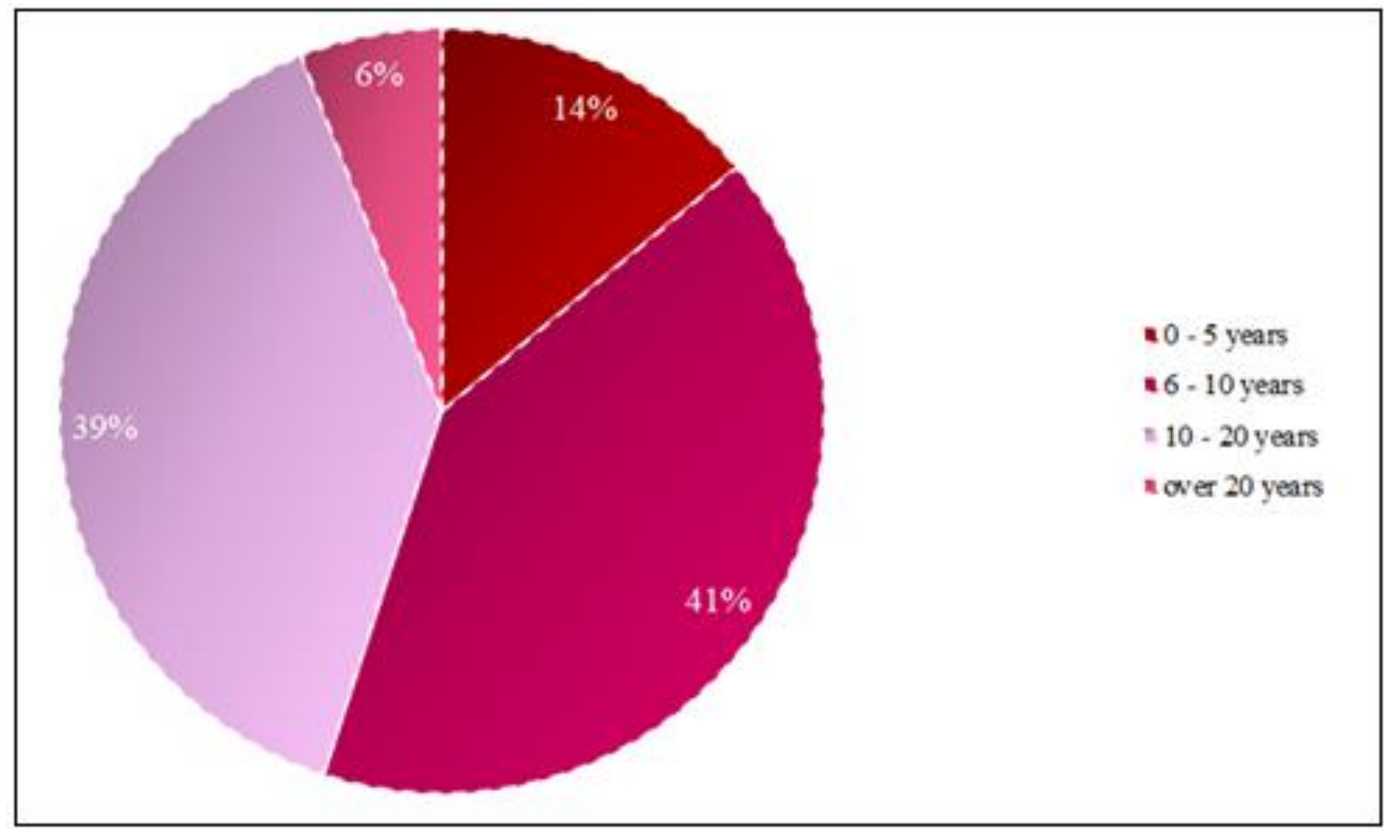

Figure 8. Level of experience of respondents in the agricultural sector

\section{CONCLUSIONS}

The research reveals that agriculture is one of the extremely important economic activities for the city of Magurele, despite the fact that it is an urban community, the relocation from rural to urban is still in a process of transition. It is important to mention that the economic direction is directed towards the development of the tertiary and quaternary sectors, while agriculture is a legacy for most respondents or a habit. The objectives of the study were met, discussing an identification of the dominant agricultural category, namely people between 35 and 55 years and a relatively high degree of involvement of the population in the agricultural sector, but in a continuous decline. The study also reveals that agriculture may still be a major source of income for respondents, despite the fact that the trend is secondary. The agricultural sector will remain permanently an activity at least secondary to the Ilfov area, in terms of extensive agricultural land, despite the fact that the general trend is to sell agricultural land to real estate developers or the development of homes that can be sold at much higher costs, which can provide peace of mind in case of giving up this field. At the same time, the study manages to combine elements of authenticity with important theoretical elements, thus continuing the specialized literature in the geographical and agricultural field, offering new potential directions for the development of these branches. 


\section{REFERENCES}

[1] Bousbaine, A.D. \& Bryant, C., 2020. Chapter 8 - Urbanization, urban agriculture and food security, Urban Ecology, Emerging Patterns and Social-Ecological Systems, pp. 131-144.

[2] Boussougou Boussougou, G. et. al, 2021. Identifying agricultural areas with potential for city connections: A regional-scale methodology for urban planning. Land Use Policy, Vol. 103, available online at: https://doi.org/10.1016/j.landusepol.2021.105321

[3] Cavailhès, J. et. al, 2004. The periurban city: why to live between the suburbs and the countryside. Regional Science and Urban Economics, Vol. 34, Issue 6. pp. 681-703.

[4] Flores, A.D. et. al, 2020. A basin-level analysis of flood risk in urban and periurban areas: A case study in the metropolitan region of Buenos Aires, Argentina. Heliyon, Vol. 6, Issue 8, available online at: https://doi.org/10.1016/j.heliyon.2020.e04517.

[5] Pintilii R.D. et. al, 2017. Socio-Economic Geography Creative economies in Romania-spatial projections and trends, Bulletin of Geography, Socio-economic Series, Vol. 37, pp 95-108.

[6] Rădoi I.V. et. al, 2020. The impact of the development of the local economy on the natural environment of the Danube Delta, Romania, Public recreation and landscape protection, pp. 489.

[7] Russo, P. et. al, 2014. Marginal periurban agricultural areas: A support method for landscape planning, Land Use Policy, Vol. 41, pp. 97-109.

[8] Teodoresc, C., \& Szemkovics, L.S., 2017. The ethno-creativity in the pilot centers in Romania and their role in the development of cultural tourism and the educational process, Geographical studies and environment protection research vol. 16, nr. 1, pp. 88-97, 2017

[9] Teodorescu C. et. al, 2019. Disfunctionalities in the Organization and Development of SPA Tourism Developed on Salt Resources in Maramureș, Romania, Public Recreation and Landscape Protection, Vol. 1, pp 101-105.

[10] Teodorescu C. et. al, 2016, Religious and cultural tourism and the socio-economic and educational implications. Quaestus Multidisciplinary Research Journal, Vol. 8, pp 227- 285.

[11] Teodorescu C. 2009. Turism cultural, Editura Transversal, Targoviste, Romania. 